Preliminary communication - Prethodno priopćenje

UDK: 637.072

\title{
Production and quality of kefir cultured butter
}

doi: $10.15567 /$ mljekarstvo.2018.0108

\author{
Yaşar Karaca', Illhan Gün², Atıf Can Seydim¹, Zeynep Banu Guzel-Seydim*
}

${ }^{1}$ Süleyman Demirel University Department of Food Engineering, 32260 Isparta, Turkey

${ }^{2}$ Mehmet Akif Ersoy University, Vocational School, 15100 Burdur,Turkey

Received - Prispjelo: 19.07.2017.

Accepted - Prihvaćeno: 17.12.2017.

\begin{abstract}
Cream is the main raw material for the butter production and reflects its properties into butter quality. Maturation of cream with appropriate starter culture is important for butter quality, sensory properties and shelf life of the end product. Kefir grains contain important probiotics for healthy nutrition including lactic acid bacteria, acetic acid bacteria, and yeasts in high numbers. The aim of this research was to determine the properties of butter produced using natural kefir culture during a 21-day cold storage. Determination of microbial, chemical and sensory properties of butter samples was carried out. Control sample (KOTE) had 6.64 log CFU g-1 Lactococcus spp. while kefir cultured butter samples had $8.58 \log \mathrm{CFU} \mathrm{g} \mathrm{g}^{-1}$. Kefir cultured butter contained $5.24 \log \mathrm{CFU} \mathrm{g}^{-1} \mathrm{~L}$. acidophilus at Day 1, while control samples did not have L. acidophilus. Acetaldehyde content of kefir cultured butter was significantly higher from the uncultured butter. According to sensory evaluation performed by 12 panelists, KKTE samples had better sensory properties than those observed in the KOTE samples.
\end{abstract}

Key words: butter, probiotic, kefir grain, lactic acid bacteria, quality, sensory properties

\section{Introduction}

In terms of economic value as well as in terms of nutrition, butter is an important dairy product. Unlike other fats and oils, butter consists of unsaturated monogenic and polyenoic fatty acids and a large number of isomers, as well as low and high molecular fatty acids. In addition, saturated fatty acids with 4, 6 and 8 carbon molecules like butyric, caproic and caprylic acids, and unsaturated acids in butter's structure like oleic and linoleic acids are in liquid form and other fatty acids are in solid form at room temperature. Thus, the presence of essential fatty acids that cannot be synthesized in humans increases the importance of butter. Besides, the fact that butter has fatty acids like butyric acid which does not exist in any other fat, enables butter to have a unique flavour. In butter production, the maturation of cream is generally carried out using a starter culture. The main flavour substances in butter production are diacetyl and acetaldehyde and are usually obtained through bacterial strains like Streptococcus cremoris and Leuconostoc mesenteroides, or their mixtures. Leuconostoc cremoris, S. lactis subsp. diacetylactis are also used for flavour development in butter production (Gajjar et al., 2015).

First scientific theories on the positive effects of probiotics were developed in the early 1900s by Elie Metchnikoff, a famous immunologist and microbiologist. Metchnikoff stated that negative effects of intestinal microflora could be overcome and thus lifespan of humans could be prolonged by consuming fermented dairy products. Commercial kefir is generally produced with using either kefir starter culture that has very limited microflora compared to unique kefir grain. Bouriie at al. (2016) clarified that health benefits of commercial kefir produced with kefir starter culture have not been performed/ not published. Kefir grains should be considered as a "starter culture mine" whose microbial diversity is not found in any other source. Kefir produced from 
kefir grains that contain lactic acid bacteria, acetic acid bacteria, and yeasts can be regarded as food containing the most natural probiotics ever known. Kefir grains are significantly rich in characteristic bacterial strains like Lactobacillus kefir, Lactobacillus parakefir, Lactobacillus kefiranofaciens and Lactobacillus kefirgranum (Guzel-Seydim et al., 2010). Regular consumption of kefir provides important therapeutic advantages to consumers such as improving digestive systems with prebiotics, probiotics, and their extra-cellular enzymes, modulation of immune system including alleviation of allergy and asthma, antibacterial and antifungal activities, improving antimutagenic and/or anticarcinogenic activity (Murofishi et al., 1986; Maeda et al., 2004; Rodriguez et al., 2005; Vinderola et al., 2006; Medrano et al., 2007; Guzel-Seydim et al., 2010; Bourrie et al., 2016).

There has been no publication so far on the production and properties of kefir cultured probiotic butter. The aim of the study is to produce butter with improved probiotic content by using natural kefir culture and to determine microbial, chemical and sensory characteristics within a 21-day cold storage.

\section{Material and methods}

\section{Butter production}

Raw cream (55 \% fat) was provided from Unsüt Dairy Plant, Süleyman Demirel University, Department of Food Engineering (Isparta, Turkey). Kefir culture made from authentic kefir grains was kindly provided from Danem Co., (Suleyman Demirel University TechnoPark, Isparta, Turkey). Butter was produced at Suleyman Demirel University Dairy pilot plant. Starter culture was not used for uncultured butter production (CONTROL). Kefir culture inoculation was $3 \%$ and cultured cream was fermented at $18^{\circ} \mathrm{C}$ for $18 \mathrm{~h}$.

\section{Determination of microbial content in butter}

Butter samples were homogenized using T25 digital Ultra-Turrax (Germany) and one gram sample was re-suspended in $9 \mathrm{~mL}$ sterile peptone water in a stomacher bag. The viable bacteria and yeast were determined by plating appropriate dilutions on agar plates. $100 \mu \mathrm{L}$ of each dilution was spread on agar plates. Differential enumeration was performed on MRS (Man, Rogosa and Sharpe Agar, Merck 1.10660, Germany) agar for Lactobacilli spp. at $37^{\circ} \mathrm{C}$ for $48 \mathrm{~h}$; on MRS-saliycin agar for L. acidophilus $37^{\circ} \mathrm{C}$ for $48 \mathrm{~h}$; on M17 agar (Merck 1.15108, Germany) for Lactococci spp. $37^{\circ} \mathrm{C}$ for $48 \mathrm{~h}$, on MRS-NNLP agar (Neomycin sulphate (Merck, Germany) (100 mg/L), nalidixic acid (Merck, Germany) (50 mg/L), lithium chloride (Merck, Germany) (3000 mg/L), paronomycin sulphate (Merck, Germany) (200 mg/L) for Bifidobacterium spp. $37^{\circ} \mathrm{C}$ for $48 \mathrm{~h}$ in a $6 \% \mathrm{CO}_{2}$ incubator and on PDA (Merck 1.10130, Germany) for yeasts at $25^{\circ} \mathrm{C}$ for 5 days. After appropriate incubations were completed, plates containing 30-300 colonies were counted. By taking into account the dilution factor, the number of viable microorganisms was expressed as colony forming units (CFU) per gram.

\section{Proximate analysis}

Butter samples were analysed for acidity level $(\mathrm{pH})$, acid value, total dry matter, and fat content according to AOAC standard method procedures (AOAC, 2000; AOAC 2006a; 2006b; 2006c; 2006d).

\section{Determination of flavour substances}

Agilent 7697A Headspace and Agilent 7890A Gas Chromatography with 5975C MS were used for determination of acetaldehyde, ethanol, acetone and diacetyl (Guzel-Seydim et al. 2000a; 2000b). Injection time was $0.08 \mathrm{~min}$; detector and injector temperature were $200{ }^{\circ} \mathrm{C}$ and $180^{\circ} \mathrm{C}$, respectively; withdrawal time was $0.5 \mathrm{~min}$; flow rate was $25 \mathrm{psi}$ (He); pressurize time $0.5 \mathrm{~min}$; needle temperature was $90^{\circ} \mathrm{C}$; thermostat time was 5 min, transfer line was $120^{\circ} \mathrm{C}$; vial oven temperature was $85^{\circ} \mathrm{C}$.

\section{Determination of fatty acid profiles}

Derivatization of fatty acid to fatty acid methyl ester (FAME) was prepared according to Ewe and Loo (2016). Determination of fatty acid profile was carried out according to Atasoglu et al. (2009). FAME was determined using a GC (Agilent 7697A Headspace) system (oven program) with a flame ionization detector (FID) and a HP-5MS (30 $\mathrm{m} \mathrm{x}$ $250 \mu \mathrm{m} \times 0.25 \mu \mathrm{m})$. The injector and detector were maintained at $220^{\circ} \mathrm{C}$ and $350{ }^{\circ} \mathrm{C}$, respectively. The column temperature was programmed as an initial temperature at $120^{\circ} \mathrm{C}$ holding for $2 \mathrm{~min}$, ramping to 
$150{ }^{\circ} \mathrm{C}$ at $5{ }^{\circ} \mathrm{C} / \mathrm{min}$ for $5 \mathrm{~min}, 170{ }^{\circ} \mathrm{C}$ at $3{ }^{\circ} \mathrm{C} / \mathrm{min}$ for $4 \mathrm{~min}$ and $230{ }^{\circ} \mathrm{C}$ at $5{ }^{\circ} \mathrm{C} / \mathrm{min}$ and holding for $20 \mathrm{~min}$. Helium was used as carrier gas with flow rate at $0.8 \mathrm{~mL} / \mathrm{min}$ (split ratio: $25: 1$ ). Identification of peaks was based on a comparison of retention time with standard FAME.

\section{Colour measurement}

$\mathrm{L}^{*}$ (whiteness to blackness), $\mathrm{a}^{*}$ (redness to greenness) and $b^{*}$ (yellowness to blueness) values of butter samples were determined by using Minolta (Minolta Corp, Ramsey, NJ, USA).

\section{Sensory analysis}

Sensory evaluation of cultured and uncultured butter samples was conducted by 12 panelists who were selected from volunteer graduate students and academic staff of the Department of Food Engineering. The panelists ( $\mathrm{n}=12$ : 8 women, 4 men, aged 19-46 years old) received a 30-h training session including basic tastes and flavour identification and using a 5-point product specific scale with references (Table 1) (Meilgard et al. 1999). The samples were presented to the panelists every week $\left(1^{\text {st }}, 7^{\text {th }}\right.$, $14^{\text {th }}$ and, $\left.21^{\text {st }}\right)$. Butter samples $(25 \mathrm{~g})$ were presented

Table 1. Fatty acid profiles of butter samples

\begin{tabular}{|c|c|c|c|}
\hline Fatty acids (\%) & $\begin{array}{l}\text { Carbon } \\
\text { number }\end{array}$ & $\begin{array}{c}\text { KOTE } \\
\text { (Control) }\end{array}$ & $\begin{array}{c}\text { KKTE } \\
\text { (Kefir cultured butter) }\end{array}$ \\
\hline Butyric acid & C4:0 & $0.698 \pm 0.140^{\mathrm{a}}$ & $0.337 \pm 0.013^{b}$ \\
\hline Caproic acid & C6:0 & $0.707 \pm 0.101^{\mathrm{a}}$ & $0.534 \pm 0.034^{b}$ \\
\hline Caprylic acid & C8:0 & $0.706 \pm 0.054^{\mathrm{a}}$ & $0.671 \pm 0.028^{b}$ \\
\hline Capric acid & $\mathrm{C} 10: 0$ & $2.547 \pm 0.133$ & $2.572 \pm 0.076$ \\
\hline Undecanoic acid & C11:0 & $0.034 \pm 0.003$ & $0.038 \pm 0.002$ \\
\hline Lauric acid & $\mathrm{Cl2:0}$ & $3.732 \pm 0.185$ & $3.852 \pm 0.132$ \\
\hline Tridecanoic acid & C13:0 & $0.069 \pm 0.006$ & $0.077 \pm 0.003$ \\
\hline Myristic acid & $\mathrm{Cl} 4: 0$ & $11.829 \pm 0.234$ & $11.739 \pm 0.435$ \\
\hline Methyl myristoleate & Cl4:1 & $1.104 \pm 0.093$ & $1.229 \pm 0.046$ \\
\hline Pentadecanoic acid & C15:0 & $1.035 \pm 0.082$ & $1.163 \pm 0.031$ \\
\hline cis-10-Pentadecenoic acid & C15:1 & $0.039 \pm 0.004$ & $0.044 \pm 0.001$ \\
\hline Palmitic acid & $\mathrm{Cl} 6: 0$ & $28.900 \pm 0.654^{\mathrm{a}}$ & $27.701 \pm 0.463^{\mathrm{b}}$ \\
\hline Palmitoleic acid & C16:1 & $1.760 \pm 0.123^{\mathrm{a}}$ & $2.011 \pm 0.052^{b}$ \\
\hline Heptadecanoic acid & $\mathrm{C} 17: 0$ & $0.579 \pm 0.040$ & $0.687 \pm 0.019$ \\
\hline cis-10-Heptadecenoic acid & C17:1 & $0.314 \pm 0.022$ & $0.369 \pm 0.010$ \\
\hline Stearic acid & $\mathrm{C} 18: 0$ & $11.586 \pm 0.176$ & $11.952 \pm 0.368$ \\
\hline trans-9-octadecenoic acid & $\mathrm{Cl} 8: \ln 9 \mathrm{t}$ & $3.951 \pm 0.098$ & $4.281 \pm 0.134$ \\
\hline Oleic acid & $\mathrm{Cl} 8 \mathrm{ln} \ln 9 \mathrm{c}$ & $25.396 \pm 0.647$ & $24.875 \pm 0.377$ \\
\hline Linolelaidic acid & $\mathrm{Cl} 8: 2 \mathrm{n} 6 \mathrm{t}$ & $1.116 \pm 0.052$ & $1.250 \pm 0.077$ \\
\hline Linoleic acid & $\mathrm{C} 18: 2 \mathrm{n} 6 \mathrm{c}$ & $3.072 \pm 0.148^{\mathrm{a}}$ & $3.531 \pm 0.101^{\mathrm{b}}$ \\
\hline Arachidic acid & C20:0 & $0.214 \pm 0.080$ & $0.183 \pm 0.059$ \\
\hline$\gamma$-Linolenic acid & $\mathrm{Cl} 18: 3 \mathrm{n} 6 \mathrm{c}$ & $0.023 \pm 0.002$ & $0.027 \pm 0.002$ \\
\hline cis-11-Eicosenoic acid & C20:1 & $0.292 \pm 0.023^{\mathrm{a}}$ & $0.429 \pm 0.065^{\mathrm{b}}$ \\
\hline Heneicosanoic acid & $\mathrm{C} 21: 0$ & $0.008 \pm 0.003^{\mathrm{a}}$ & $0.026 \pm 0.009^{b}$ \\
\hline cis-1 1,14-Eicosanoic acid & C20:2 & ND & $0.008 \pm 0.008$ \\
\hline Behenic acid & $\mathrm{C} 22: 0$ & $0.028 \pm 0.004^{\mathrm{a}}$ & $0.047 \pm 0.005^{b}$ \\
\hline cis-8,11,14-Eicosadienoic acid & C20:3n6 & $0.087 \pm 0.021^{\mathrm{a}}$ & $0.149 \pm 0.018^{\mathrm{b}}$ \\
\hline cis-11,14,17-Eicosatrienoic acid & $\mathrm{C} 20: 3 \mathrm{n} 3$ & ND & ND \\
\hline Erucic acid & C22: $\ln 9$ & ND & ND \\
\hline Arachidonic acid & $\mathrm{C} 20: 4 \mathrm{n} 6$ & $0.143 \pm 0.015$ & $0.179 \pm 0.021$ \\
\hline Tricosanoic acid & C23:0 & ND & ND \\
\hline cis-13,16-Docasadienoic acid & $\mathrm{C} 22: 2 \mathrm{n} 6$ & ND & ND \\
\hline cis-5,8,11,14,17-Eicosapentaenoic acid & $\mathrm{C} 20: 5 \mathrm{n} 3$ & $0.031 \pm 0.003$ & $0.040 \pm 0.003$ \\
\hline
\end{tabular}

a,b Mean difference between KOTE and KKTE $(\mathrm{P}<0,05)$ 
in sample cups with plastic lids with three digit codes. The panelists were asked to evaluate the colour, appearance, odour, taste, texture (hand), texture (mouth) and overall acceptability, based on a 5 point scale; between like extremely $=5$ point and dislike extremely $=1$ point (Lawless and Heymann 1999; Ertekin and Güzel-Seydim 2010).

Results are expressed as mean values and standard deviation. Different superscripts within a group denote a statistically significant difference $(\mathrm{P}<0.05)$.

\section{Statistical analyses}

Data analyses were performed using SPSS statistical software Version 22 (SPSS Inc., Chicago, IL). Microbial and chemical data were analyzed using repeated measurement ANOVA. A factorial arrangement was set up to study the influence of two treatment and four storage time using 3 replicates. Tukey A test was performed for group means comparison. $\mathrm{P}$ value $<0.05$ was considered statistically significant for all analysis.

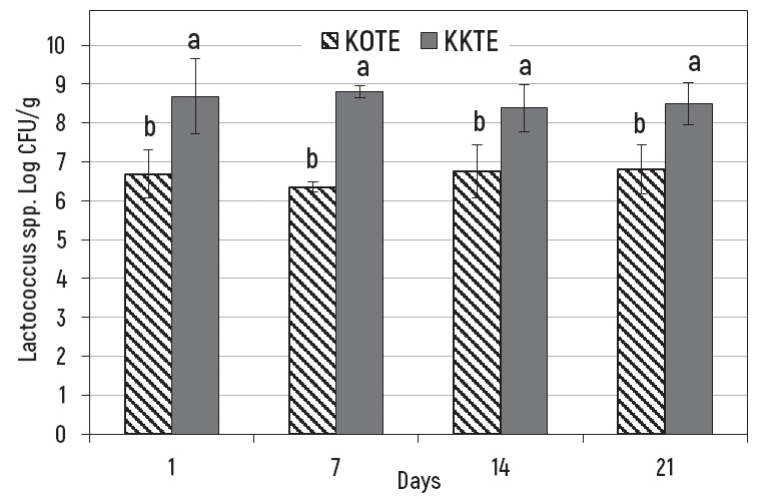

Figure 1b. Lactococcus spp. content of butters during the storage period

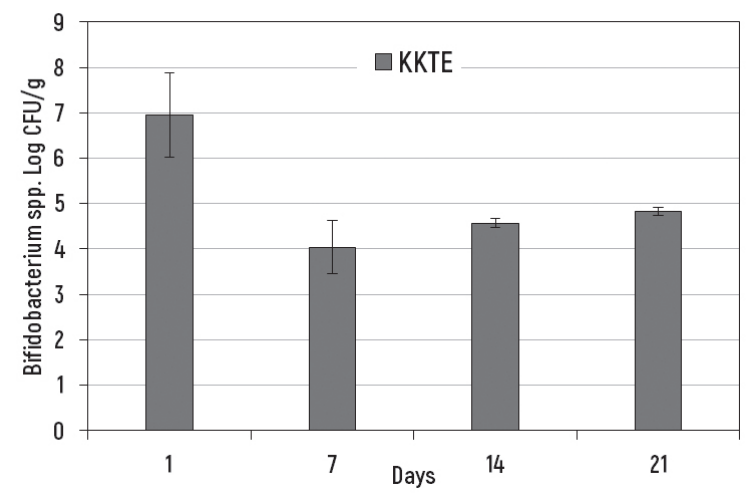

Figure 1d. Bifidobacterium spp. content of kefir cultured butter during storage

\section{Results and discussion}

In this study, two types of butter were produced without a starter culture as a control (KOTE) sample and with a natural kefir culture (KKTE). Microbiological changes in $1^{\text {st }}, 7^{\text {th }}, 14^{\text {th }}$ and $21^{\text {st }}$ day of butter samples were shown in Figures la-e. Kefir cultured butter sample (KKTE) had significantly higher (approximately $3.5 \mathrm{log}$ ) amounts of Lactobacillus spp. than uncultured butter $(\mathrm{P}<0.05)$. Lactococci spp.

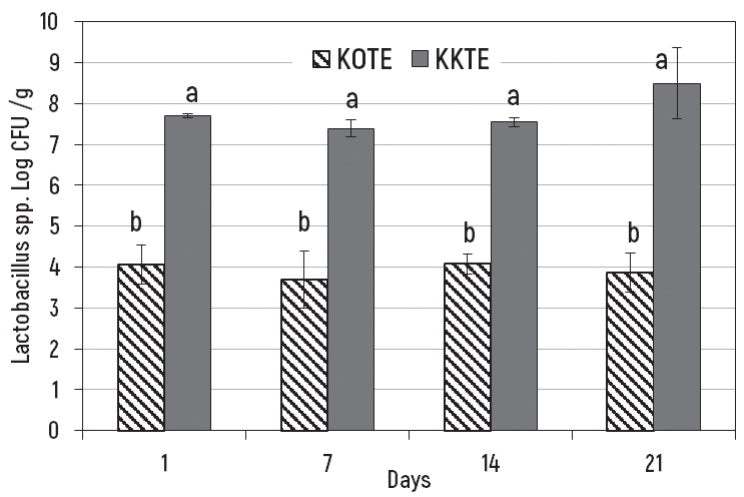

Figure 1a. Lactobacillus spp. content of butters during the storage period

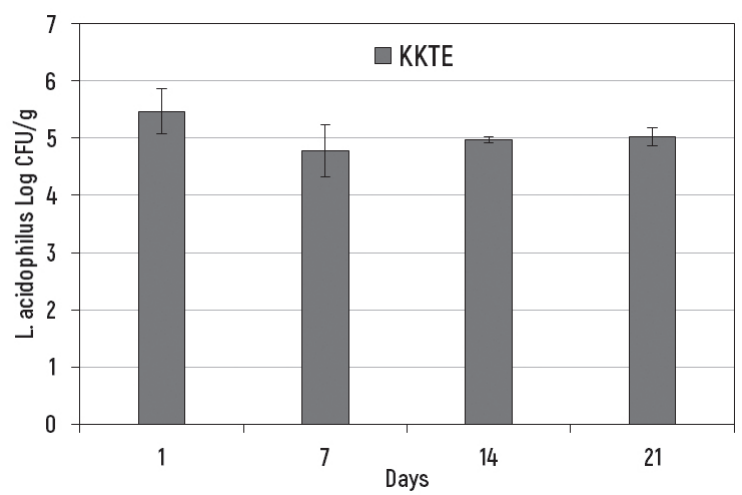

Figure 1c. L. acidophilus spp. content of kefir cultured butters during the storage period

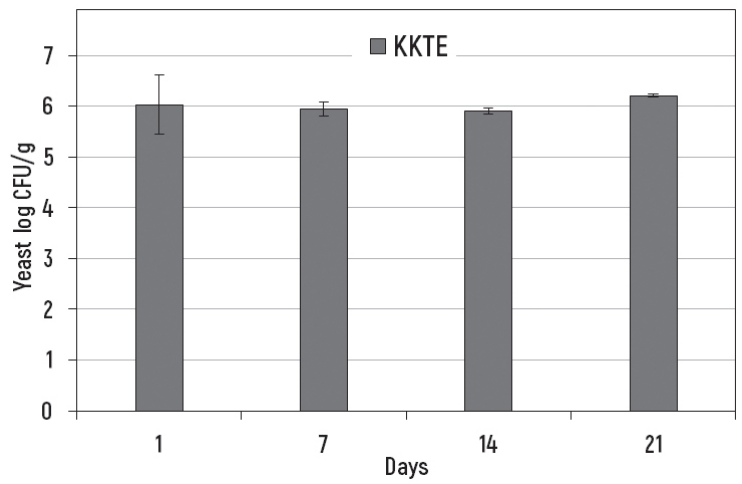

Figure le. Yeast contents during the storage period the samples 
were $8.68 \log \mathrm{CFU} \mathrm{g} \mathrm{g}^{-1}$ and $6.68 \log \mathrm{CFU} \mathrm{g^{-1 }}$ at the 1st day of storage and $8.49 \log \mathrm{CFU} \mathrm{g}^{-1}$ and $6.80 \log \mathrm{CFU} \mathrm{g}{ }^{-1}$ at the last day of cold storage in kefir cultured butter and uncultured butter, respectively $(\mathrm{P}<0.05)$. Microbial counts in both butter samples were significantly $(\mathrm{P}>0.05)$ affected by maturation with natural kefir culture whereas cold storage didn't affect microbial content. Ewe and Loo (2016) investigated the effect of cream fermentation on microbiological, physicochemical and rheological properties of Lactobacillus helveticusbutter. They reported that L. helveticus content reduced in cream after churning from $8.67 \mathrm{log} \mathrm{CFU} \mathrm{g}^{-1}$ to $5.72 \log$ CFU g-1.

According to our results, higher amounts of lactic acid bacteria were found in butter samples. $L$. acidophilus, Bifidobacterium spp. and yeasts were present in kefir-cultured butter while KOTE sample did not contain any of those microorganisms $(\mathrm{P}<0.05)$. The slight decrease in Bifidobacterium spp. was noted in kefir cultured butter sample during the cold storage period $(\mathrm{P}<0.05)$. Kefir produced from kefir grains contained yeasts, mainly Saccharomyces spp. and Kluyveromyces spp., and therefore it was obvious that yeast in kefir culture propagated in cream during maturation. The presence of lactic acid bacteria, L. acidophilus, Bifidobacterium spp. and yeasts are characteristic to kefir grain microflora (Kok Tas et al., 2011; Bourrie et al., 2016) implicated that microflora in natural kefir culture was able to develop properly in cream that was used in butter production. Ekinci et al. (2008) determined the effects of using various probiotic bacteria (L. acidophilus, B. bifidum, S. thermophilus and L. bulgaricus, P. thoenii (jensenii) P126, and P. jensenii B1264 and a mixed culture of L. acidophilus, B. bifidum, S. thermophilus and L. bulgaricus) on the fatty acid profiles of creams; the microbial results of this study were similar to our results and verified that fermented cream contained high amounts of microorganisms.

The chemical composition of butter samples during storage period are presented in Table 2 . The $\mathrm{pH}$ values of kefir cultured butters (KKTE) were 4.78 and 4.12 at the first and the last storage day, respectively. However, $\mathrm{pH}$ values of uncultured butter samples (KOTE) were 6.29 and 5.51 at the first and last storage day $(\mathrm{P}<0.05)$, respectively. Since cultured butter had microbial activity due to kefir culture inoculation, the microflora used the lactose for lactic acid production. $\mathrm{pH}$ decrease was insignificant for both cultured and uncultured butters $(\mathrm{P}>0.05)$. During cold storage. Acid values (mg KOH/l g of fat) of KKTE sample changed between 0.83 and $0.91 \mathrm{mg} \mathrm{KOH} / 1 \mathrm{~g}$ of fat while the titration values of KOTE samples changed between 0.54 and $0.61 \mathrm{mg} \mathrm{KOH} / 1 \mathrm{~g}$ of fat $(\mathrm{P}<0.05)$. Acid values of both samples increased $(\mathrm{P}>0.05)$ during storage. Ewe and Loo (2016) reported similar results since acid values increased from $1.22 \mathrm{mg} / \mathrm{g}$ fat in control cream sample to $1.77 \mathrm{mg} / \mathrm{g}$ fat in fermented cream, respectively. Koczon et al. (2008) reported that acid values of unfermented butters with $82 \%$ fat increased from 0.450 to 2.92 during eight-week storage. The occurrence of a slight increase in acidity in control butter sample during storage resulted from its own natural flora. Thermophilic lactic acid bacteria and natural enzymes could be involved since the cream was pasteurized. Fat contents were determined as $85 \%$ and dry matter contents were determined as $89 \%$ regardless of if the kefir culture were used in butter samples or not (Table 2). Formation of important metabolic products such as acetaldehyde, diacetyl, and acetone occur during fermentation. Kefir culture has potential to produce significant content of acetaldehyde, acetone, and ethanol due to the high content of lactic acid bacteria and yeasts. The main aromatic compound in butter is diacetyl; however, in the samples diacetyl content was not determined (Table 3).

The amount of acetaldehyde in butter samples at the $1^{\text {st }}$ day was $0.095 \mathrm{mg} / \mathrm{kg}$ in kefir cultured butter and $0.055 \mathrm{mg} / \mathrm{kg}$ in KOTE sample $(\mathrm{P}<0.05)$. Beshkova et al. (2002) determined the acetaldehyde content of kefir after fermentation as $18.1 \mathrm{mg} / \mathrm{L}$, and in it was determined as $15.27 \mathrm{mg} / \mathrm{L}$ at the $7^{\text {th }}$ day. Güzel-Seydim et al. (2000) determined the amount of acetaldehyde in the $21^{\text {st }}$ day as $11 \mathrm{mg} / \mathrm{L}$ in their studies. Ertekin and GüzelSeydim (2010) identified a decrease for acetaldehyde for the $1^{\text {st }}$ and $7^{\text {th }}$ days from 5.84 to $2.89 \mathrm{mg} / \mathrm{L}$. It was expected that the amount of acetaldehyde would not be as high as in butter samples as in kefir. However, the positive effect of kefir culture on flavour components was noted from the amount of acetaldehyde that occurs even in low concentration. Acetone contents of cultured and uncultured butters were 1.40 and $0.44 \mathrm{mg} / \mathrm{kg}$, respectively. 
Fatty acid profiles of kefir cultured and uncultured butters were presented in Table 1. It was noticed that low carbon fatty acids such as butyric, caproic and caprylic, were significantly lowered in kefir cultured butters which may be associated to the lower carbon aromatic compound formation $(\mathrm{P}<0.05)$. Ewe and Loo $(2016)$ reported that fermented (L. helveticus) butter contained higher health beneficial unsaturated fatty acids than the control butters and thus product became softer; in our study kefir cultured butters had also higher amounts of behenic, heneicosanoic and eicosadienoic acids. Probiotic bacteria were found to be able to synthesize the unsaturated fatty acids during fermentation (Guzel-Seydim et al., 2006; Ekinci et al., 2008; Rodríguez-Alcalá et al., 2013).
Colour measurements of butter samples that were carried out according to CIE $\mathrm{L}^{*}, \mathrm{a}^{*}$ and $\mathrm{b}^{*}$ colour system are shown in Table 4. According to results of the colour analysis, there was not a significant difference between the averages of $\mathrm{L}^{*}$ values in the samples during storage $(\mathrm{P}>0.05)$. Cultured and uncultured butter samples were evaluated in terms of colour, appearance, aroma, consistency, texture and flavour characteristics (Figure 2). Colour scores were 4.46-4.33 and 4.29-4.00; in fermented and control butter samples, respectively. Aroma scores were 4.17-3.86 and 3.83-3.58 in fermented and control butter samples, respectively. Appearance scores were 4.08-4.17 and 4.21-3.38 in fermented and control butter samples, respectively.

Table 2. Chemical analysis of butter samples during storage results butter

\begin{tabular}{|c|c|c|c|c|}
\hline \multicolumn{5}{|c|}{$\mathrm{pH}$} \\
\hline Samples/Storage times & 1 & 7 & 14 & 21 \\
\hline KKTE & $4.78 \pm 0.02^{\mathrm{a}, \mathrm{x}}$ & $4.51 \pm 0.04^{\mathrm{a}, \mathrm{x}}$ & $4.32 \pm 0.02^{\mathrm{a}, \mathrm{y}}$ & $4.12 \pm 0.01^{\mathrm{a}, \mathrm{z}}$ \\
\hline KOTE & $6.29 \pm 0.03^{b, x}$ & $6.03 \pm 0.02^{b, x}$ & $5.72 \pm 0.001^{b, y}$ & $5.51 \pm 0.02^{b, y}$ \\
\hline \multicolumn{5}{|c|}{ Acid Value (mg KOH/l g of fat) } \\
\hline Samples/Storage times & 1 & 7 & 14 & 21 \\
\hline KKTE & $0.83 \pm 0,009^{a, x}$ & $0.88 \pm 0,005^{\mathrm{a}, \mathrm{x}}$ & $0.90 \pm 0,003^{a, x}$ & $0.91 \pm 0,007^{\mathrm{a}, \mathrm{y}}$ \\
\hline KOTE & $0.54 \pm 0,005^{b, x}$ & $0.54 \pm 0,002^{b, x}$ & $0.57 \pm 0,006^{b, y}$ & $0.61 \pm 0,009^{b}, y$ \\
\hline \multicolumn{5}{|c|}{$\%$ Fat } \\
\hline Samples/Storage times & 1 & 7 & 14 & 21 \\
\hline KKTE & $85.18 \pm 0.03$ & $85.15 \pm 0.01$ & $84.99 \pm 0.02$ & $85.08 \pm 0.05$ \\
\hline KOTE & $85.43 \pm 0.30$ & $85.43 \pm 0.30$ & $85.16 \pm 0.05$ & $85.11 \pm 0.08$ \\
\hline \multicolumn{5}{|c|}{$\%$ Dry matter } \\
\hline Samples/Storage times & 1 & 7 & 14 & 21 \\
\hline KKTE & $89.99 \pm 0.45$ & $89.99 \pm 0.06$ & $89.99 \pm 0.22$ & $89.99 \pm 0.07$ \\
\hline KOTE & $89.99 \pm 0.03$ & $89.99 \pm 0.08$ & $89.99 \pm 0.28$ & $89.99 \pm 0.07$ \\
\hline
\end{tabular}

a,bMean difference between KOTE and KKTE. ${ }^{x, y}$ Mean difference between the same sample during storage time $(\mathrm{P}<0,05)$

Table 3. Aroma substances in butter samples $(\mathrm{mg} / \mathrm{kg})$

\begin{tabular}{cccccc}
\hline \multirow{2}{*}{ Sample } & Aroma markers & \multicolumn{4}{c}{ Storage time (days) } \\
\cline { 3 - 6 } & & 1 & 7 & 14 & 21 \\
\hline \multirow{2}{*}{ KKTE } & Acetaldehyde & $0.095^{\mathrm{a}}$ & $0.050^{\mathrm{a}}$ & $0.025^{\mathrm{a}}$ & $0.011^{\mathrm{a}}$ \\
\cline { 2 - 5 } & Acetone & $1.40^{\mathrm{A}}$ & $0.82^{\mathrm{A}}$ & $1.13^{\mathrm{A}}$ & $2.64^{\mathrm{A}}$ \\
\hline \multirow{2}{*}{ KOTE } & Acetaldehyde & $0.055^{\mathrm{b}}$ & $0.025^{\mathrm{b}}$ & $0.011^{\mathrm{b}}$ & $0.014^{\mathrm{b}}$ \\
\cline { 2 - 5 } & Acetone & $0.44^{\mathrm{B}}$ & $0.49^{\mathrm{B}}$ & $1.56^{\mathrm{A}}$ & $1.81^{\mathrm{B}}$ \\
\hline
\end{tabular}

Results are expressed as mean values and standard deviations.

Different superscripts within a group (i.e. within each parameter) denote a statistically significant difference $(\mathrm{P}<0.05)$ 

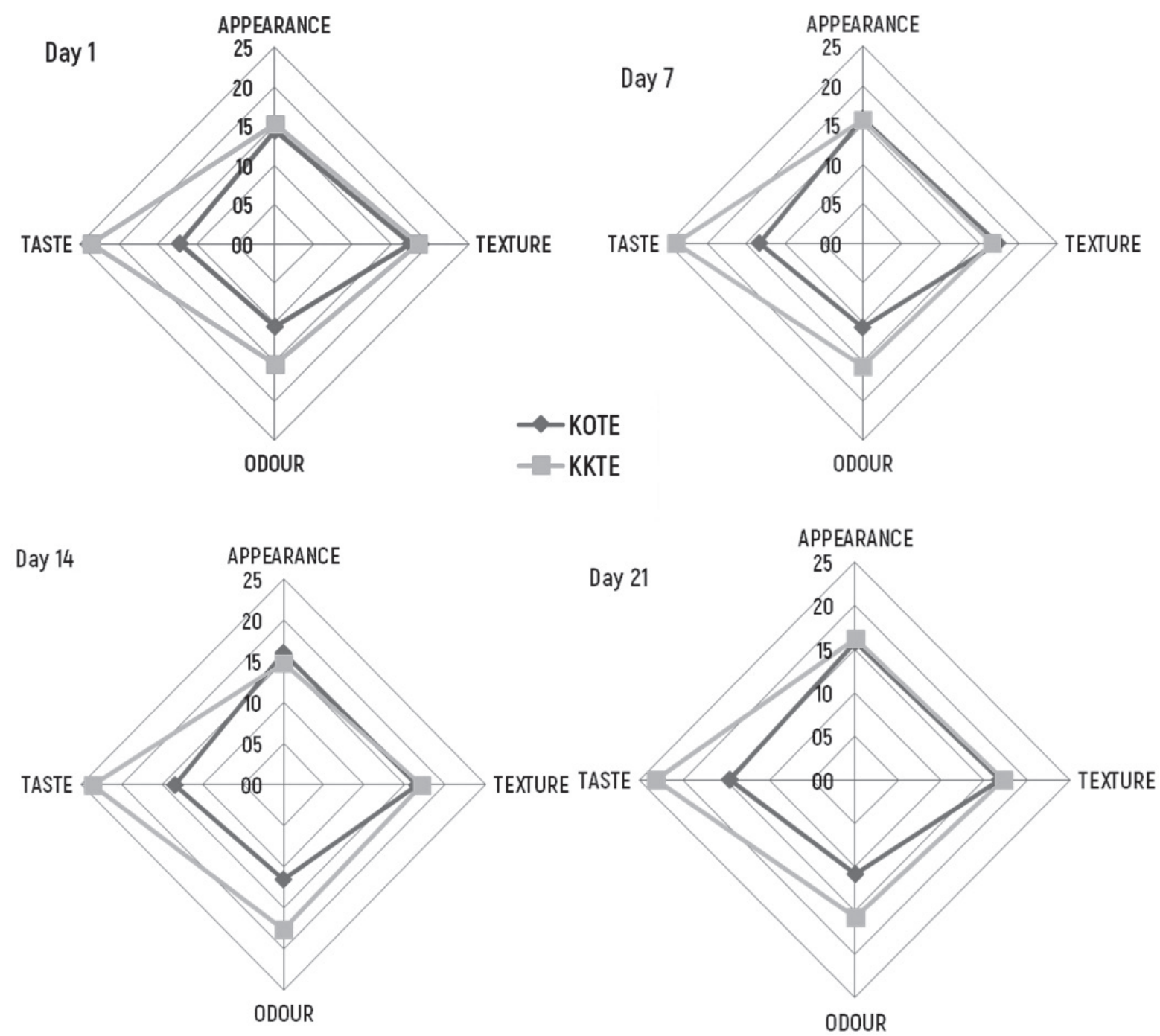

Figure 2. Sensory evaluation of butter samples during storage

Table 4. CIE L*, a* and $b^{*}$ values of butter samples during storage

CIE L*

\begin{tabular}{ccccc}
\hline Samples/Storage time (days) & 1 & 7 & 14 & 21 \\
\hline KKTE & $94.82 \pm 0.43$ & $93.57 \pm 0.61$ & $93.36 \pm 0.19^{\mathrm{a}}$ & $87.95 \pm 0.54$ \\
\hline KOTE & $93.92 \pm 0.19$ & $92.83 \pm 0.59$ & $90.88 \pm 0.55^{\mathrm{b}}$ & $88.78 \pm 0.65$ \\
\hline \multicolumn{5}{c}{ CIE a $^{*}$} \\
\hline Samples/Storage time (days) & 1 & 7 & 14 & 21 \\
\hline KKTE & $-3.08 \pm 0.06$ & $-3.35 \pm 0.12$ & $-3.15 \pm 0.04$ & $2.80 \pm 0.06^{\mathrm{a}}$ \\
\hline KOTE & $-3.05 \pm 0.09$ & $-3.13 \pm 0.13$ & $-2.97 \pm 0.07$ & $3.27 \pm 0.10^{\mathrm{b}}$ \\
\hline \multicolumn{5}{c}{${\text { CIE } \mathrm{b}^{*}}$} \\
\hline Samples/Storage time (days) & 1 & 7 & 14 & 21 \\
\hline KKTE & $15.39 \pm 0.55$ & $14.79 \pm 0.16$ & $14.12 \pm 0.12$ & $14.67 \pm 0.18$ \\
\hline KOTE & $14.41 \pm 0,16$ & $14.79 \pm 0.16$ & $14.12 \pm 0.12$ & $14.67 \pm 0.18$ \\
\hline
\end{tabular}

a,bMeans in the table shows the differences between cultured and uncultured samples at the same storage day 
Consistency scores were 4.50-4.38 and 4.133.75 in fermented and control butter samples, respectively. Similar to our consistency scores, Ewe and Loo (2016) noted that fermented butter was softer than the control sample due to changes in fatty acid composition during fermentation. Texture scores were 4.25-4.08 and 4.00-3.38 in fermented and control butter samples, respectively. Flavour scores were 4.58-3.83 and 4.00-3.08 in fermented and control butter samples, respectively $(\mathrm{P}<0.05)$. All sensory parameters of kefir cultured butter at each storage day were more desirable than the uncultured butter $(\mathrm{P}<0.05)$.

\section{Conclusions}

In this study, kefir cultured butter had unique microbial and sensorial characteristics. Fermentation of cream affected the microflora and composition of fatty acids; thus flavour composition that made the product more delicious and softer. Kefir grains could be used as a natural starter culture for butter.

\section{Acknowledgments}

We thank Süleyman Demirel UniversityResearch funding (SDU-BAP; Project number: 3373-YL2-12) for financial support.

\section{Proizvodnja i kvaliteta maslaca inokuliranog kefirnom kulturom}

Vrhnje je glavna sirovina za proizvodnju maslaca te značajno utječe na njegova svojstva i kvalitetu. U proizvodnji maslaca na njegovu kvalitetu, senzorska svojstva i trajnost krajnjeg proizvoda u velikoj mjeri utječe i zrenje vrhnja s odgovarajućom starter kulturom. Kefirna zrnca u velikom broju sadržavaju probiotike važne za zdravu prehranu te ostale bakterije mliječne kiseline, bakterije octene kiseline i kvasce. Cilj ovog istraživanja bio je utvrditi svojstva maslaca proizvedenog pomoću kefirne kulture tijekom 21-dnevnog hladnog skladištenja (mikrobna, kemijska i senzorska svojstva). Kontrolni uzorak (KOTE) sadržavao je 6,64 log CFU g-1 Lactococcus spp., dok su kefirni uzorci maslaca (KKTE) sadržavali 8,58 log CFU g-1 ${ }^{-1}$ Kefirni maslac sadržavao je 5,24 log CFU g-1 soja L. acidophilus prvog dana, dok kontrolni uzorak nije sadržavao L. acidophilus. Sadržaj acetaldehida kefir-kultiviranog maslaca bio je znatno veći od kontrolnog maslaca. Prema ocjeni 12 panelista, uzorci KKTE imali su bolja senzorska svojstva od KOTE uzoraka.

Ključne riječi: maslac, probiotik, kefirno zrno, bakterije mliječne kiseline, kvaliteta, senzorska svojstva

\section{References}

1. AOAC International (2000): Official Methods of Analysis. 969.17: Acid value of butterfat. 17th ed AOAC International. Maryland

2. AOAC International (2006a): Official Methods of Analysis. 947.05: Acidity, titrimetric methods. $18^{\text {th }}$ ed AOAC International, Arlington, VA

3. AOAC International (2006b): Official Method 990.20: Solids (Total) in Milk. $18^{\text {th }}$ ed AOAC International, Arlington, VA

4. AOAC International (2006c): Official Method 2000.18: Fat Content of Raw and Pasteurized Whole Milk. 18 $8^{\text {th }}$ ed AOAC International, Arlington, VA

5. AOAC International (2006d): Official Method 942.05: Ash Determination. $18^{\text {th }}$ ed AOAC International, Arlington, VA

6. Atasoglu, C., Uysal-Pala, C., Karagül-Yüceer, Y. (2009): Changes in milk fatty acid composition of goats during lactation in a semi-intensive production system. Archiv Tierzucht 52, 627-636.

7. Beshkova, D.M., Simova, E.D., Simov, Z.I. (2002): Pure cultures for making kefir. Food Microbiology 19, 537-544. https://doi.org/10.1006/fmic.2002.0499

8. Bourrie, B.C.T., Willing, B.P., Cotter, P.D. (2016): The microbiota and health promoting characteristics of the fermented beverage kefir. Frontiers in Microbiology 7, 647. https://doi.org/10.3389/fmicb.2016.00647

9. Ertekin, B., Guzel-Seydim, Z.B. (2010): Effect of fat replacers on kefir quality. Journal of the Science of Food and Agriculture 90, 543-548. https://doi.org/10.1002/jsfa.3855

10. Ekinci, F.Y., Okur, O.D., Ertekin, B., Guzel-Seydim, Z. (2008): Effects of probiotic bacteria and oils on fatty acid profiles of cultured cream. European Journal of Lipid Science and Technology 110, 216-224. https://doi.org/10.1002/ejlt.200700038

11. Gajjar, H., Shridhar, J., Hasmukh, M. (2015): Probiotic assessment of fermented milk product buttermilk made from different milk samples with special reference to lactic acid bacteria. Horizons of Holistic Education 22, 149-158. 
12. Güzel-Seydim, Z.B., Seydim, A.C., Greene, A.K., Bodine, A.B. (2000a): Determination of organic acids and volatile flavor substances in kefir during fermentation. Journal of Food Composition and Analysis 13, 35-43. https://doi.org/10.1006/jfca.1999.0842

13. Güzel-Seydim, Z.B., Seydim, A.C., Greene, A.K. (2000b): Organic acids and volatile flavor components evolved during refrigerated storage of kefir. Journal of Dairy Science 83, 275-277. https://doi.org/10.3168/jds.S0022-0302(00)74874-0

14. Guzel-Seydim, Z., Greene, A.K., Tas, T. (2006): Determination of Antimutagenic properties of some fermented milks including changes in the total fatty acid profiles including CLA. International Journal of Dairy Technology 59, 209-215. https://doi.org/10.1111/j.1471-0307.2006.00265.x

15. Güzel-Seydim, Z., Kök-Taş, T., Greene, A.K. (2010): Kefir and Koumiss, Microbiology, and Technology. In Yildız F (ed) Development and Manufacture of Yogurt and Other Functional Dairy Products. CRC Press Taylor and Francis, London, pp 143-163.

16. IBM Corp. Released (2013): IBM SPSS Statistics for Windows, Version 22.0. Armonk, NY: IBM Corp.

17. Koczon, P., Gruczynska, E., Kowalski, B. (2008): Changes in the acid value of butter during storage at different temperatures as assessed by standard methods or by FT-IR Spectroscopy. American Journal of Food Technology 3, 154-163. https://doi.org/10.3923/ajft.2008.154.163

18. Kök Tas, T., Ekinci,Y., Guzel-Seydim,Z.B. (2011): Identification of microbial flora in kefir grains sourced from three regional universities in Turkey. Journal of International Dairy Technology 65 (1), 126-131.
19. Lawless, H.T., Heymann, H. (1999): Sensory Evaluation of Food, Principles and Practices. Chapman and Hall, New York.

20. Maeda, H.X.Z., Omura, K., Suzuki, S., Kitamura, S. (2004): Structural characterization and biological activities of an exopolysaccharide kefiran produced by Lactobacillus kefiranofaciens WT-2B(T). Journal of Agricultural and Food Chemistry 52, 5533-5538. https://doi.org/10.1021/jf049617g

21. Meilgaard, M., Civille, G.V., Carr, B.T. (1999): Sensory Evaluation Techniques. $3^{\text {rd }}$ Ed. CRC Press, USA. https://doi.org/10.1201/9781439832271

22. Medrano, M., Pérez, P.F., Abraham, A.G. (2008): Kefiran antagonizes cytopathic effects of Bacillus cereus extracellular factors. International Journal of Food Microbiology 122, 1-7. https://doi.org/10.1016/j.ijfoodmicro.2007.11.046

23. Murofushi, M., Shiomi, M., Aibara, K. (1983): Effect of orally administered polysaccharide from kefir grain on delayed-type hypersensitivity and tumor growth in mice. Japanese Journal of Medical Science and Biology36, 49-53. https://doi.org/10.7883/yoken1952.36.49

24. Rodrigues, K., Caputo, L., Carvalho, J., Evangelista, J., Schneedorf, J. (2005): Antimicrobial and healing activity of kefir and kefiran extract. International Journal of Antimicrobial Agents 25, 404-408. https://doi.org/10.1016/j.ijantimicag.2004.09.020

25. Vinderola, G., Perdigon, G., Duarte, J., Farnworth, E. (2006): Effects of the oral administration of the products derived from milk fermentation by kefir microflora on immune stimulation. Journal of Dairy Research 73, 472-479. https://doi.org/10.1017/S002202990600197X 